\title{
Teacher Awareness About Multicultural in Curriculum Management and Instructional Development in Senior High School
}

\author{
Yohanes Kadek Ariana \\ Department of Educational Management \\ Postgraduate, Universitas Negeri Malang, Indonesia \\ kadekariana78@gmail.com
}

\author{
Ali Imron \\ Department of Educational Administration \\ Universitas Negeri Malang, Indonesia \\ ali.imron.fip@um.ac.id
}

\author{
Nurul Ulfatin \\ Department of Educational Administration \\ Universitas Negeri Malang, Indonesia \\ nurul.ulfatin.fip@um.ac.id
Maisyaroh
Department of Educational Administration
Universitas Negeri Malang, Indonesia
maisyaroh.fip@um.ac.id

\begin{abstract}
Teacher awareness about multiculturalism in curriculum and instructional management has not been widely studied, although it is very much needed in pluralistic societies such as in Indonesia. The purpose of this study was to determine the level of teacher awareness about multicultural in curriculum and instructional management at SMAK Kesuma West Nusa Tenggara. Teacher awareness data were obtained from 34 teachers using questionnaires, and the level of awareness was measured based on the average awareness index (\%) and contribution factor $(\%)$. The results show that teacher awareness about multiculturalism is very high, but the contribution factor is still low.
\end{abstract}

Keywords: teacher awareness, multicultural, curriculum management, instructional development

\section{INTRODUCTION}

Teachers' awareness of multicultural education plays an important role in education, because teachers continue to be required to be able to deliver students to become citizens who have social sensitivity and tolerance amid challenges of diversity. Teachers in curriculum management act as planners (planners), executors and managers (organizers) and appraisers (evaluators), therefore teacher awareness about multicultural becomes important to study.

Multicultural education is a broad and multidimensional concept (Banks \& Banks, 2010), and is seen as a reform movement in educational institutions to provide equal opportunities (equality and justice) for all students to achieve academic achievement (Banks, 2006; Smith, 2009; Gollnick and Chinn, 2009). Today schools continue to be urged by various groups to involve the community in developing curricula with the aim of promoting moral teachings to improve academic achievement for all students (Hampden-Thomson et al, 2015). In fact, the idea of multicultural education both in curriculum design and its implementation in schools is not easy, including in Indonesia.

Various studies on multicultural topics in Indonesia show that the concept of multiculturalism has not been clearly adopted to be taught in schools, for several reasons: (1) the government does not develop a clear vision of multicultural education that can bind all school components in an integrated manner to educate students about multiculturalism (Raihani, 2011), (2) teachers do not understand the concept of multicultural education (Herimanto, 2014), are not dedicated in teaching multicultural values to students (Hoon, 2013b), and (3) the contents of the school curriculum do not provide much space to teach concepts and multicultural values (Listia, Arham and Gogali, 2007; and Lie (2000). These results indicate that the adoption of multicultural values in curriculum development and teaching in schools is not yet optimal.

The curriculum becomes the direction of an educational goal, and guidelines for teachers in carrying out learning, according to Braslavsky (1999) curriculum contains the basics of education whose contents relate to the amount of time available, learning experience, teacher characteristics, methods, resources and evaluation. Other experts reveal that school curricula are both formal and informal values and processes in which students gain knowledge and understanding, develop skills and change attitudes and values with the help of schools (Doll, 1996), while according to Dulton (1996) the curriculum is experiences gained students at school. From the opinion of the experts, it was concluded that the curriculum as an experience and learning process is planned and organized with certain methods and strategies by the teacher and supporting facilities to achieve predetermined educational goals in the form of students' understanding, attitudes and skills in a specified period of time.

On the other hand, teacher mastery of student psychology is very important in the learning process (Ratnawati, 2017) because the learning process cannot be separated from the influence of student psychological factors such as intelligence, attitudes, talents, interests and student motivation (Slameto, 2010). The ability of teachers to understand students' psychological diversity and integrate multicultural values in instructional development is a challenge that is not easy for teachers.

This effort is very dependent on the role of school leaders in this case is the principal as a policy maker in curriculum development in his school and the teacher as implementing the curriculum in the learning process. For example, the principal assigns and ensures that the curriculum in each school must answer the learning needs of all students (Furman, 2012; Ylimaki \& Jacobson, 2012), or the school provides education that contains multicultural 
values (Keskin, 2018) and also there needs to be interaction from various social aspects (Mitchell, 2010).

In the development of a multicultural curriculum, there are two important questions: which multicultural values should be developed and how are multicultural developments in the context of the curriculum and instructional? The first question, about multicultural values that can be developed in schools, according to Lie (2014) can take or adopt multicultural values from the experience of other countries or schools in accordance with the multiculturalism policy that will be developed, as done in South Korea (Simmons, 2016) and in Hong Kong.

This gives the meaning that multiculturalism does not reduce diversity but determines principles and procedures in which differences can be renegotiated in the name of justice (Arneil \& MacDonald, 2010). In Ireland, the value of multicultural curricula at the basic education level emphasizes the value of diversity and citizenship more than the curriculum for secondary education (Faas \& Ross, 2012), while in Hong Kong the development of values related to identity and culture is considered less, compared to Taiwan which has been constructed concept of identity through broader policies (Jackson, 2014). Likewise, in Indonesia, for example in Kalimantan, the value that is more emphasized is transformative citizenship education because the area is prone to ethnic conflict (Nayaka, 2018).

The second question related to how to develop multiculturalism in the context of its curriculum and instructional work has been explained by several experts. The multicultural curriculum and pedagogy can be developed in response to cultural values and knowledge / experiences previously possessed by students (Bennett 2001; Gay 2013). Banks \& Banks (2004) describe five dimensions that must exist in the development of a multicultural curriculum, first, the existence of content integration that involves diversity in one educational culture with the main goal of eradicating prejudice. Secondly, knowledge construction is realized by knowing and comprehending comprehensively the diversity that exists. Third, the reduction of prejudice reduction which is born from the interaction between diversity in educational culture. Fourth, pedagogic equity / equity (equity pedagogy) which gives equal space and opportunity to every diverse element. Fifth, empowering school culture (empowering school culture). The fifth thing is the goal of multicultural education, namely that schools become elements of social alleviation (social transformation) of unequal community structures into equitable structures.

While according to Gollnick and Chinn (2009) there are 6 basic assumptions that will support multicultural education, namely: (1) Schools must see culture, values, and beliefs as strengths are not obstacles, (2) Schools must be models for expression of human rights humans and respect for cultural and group differences, (3) Social justice and equality for all people must be very important in curriculum design and implementation, (4) The attitudes and values needed for the development of democratic societies can be promoted in schools, (5) Schools can promote knowledge, skills, and tendencies (i.e. attitudes, values, perceptions, and comments) to help students from the diversity of study groups and (6) educators can work together with families and communities to create an environment that supports multiculturalism. Whereas according to Raihani (2017) there are two dimensions to developing multicultural education in Indonesia, first, focused on developing an understanding of cultural diversity to develop student attitudes, and second, focused on creating a school environment as a place for students to experience the same quality of education. The development of a multicultural curriculum must meet two requirements, namely the curriculum is not too narrow because it has to familiarize students with representative forms of various cultures and the curriculum implementation process must trigger a useful dialogue and be able to develop students' critical assessment of what is taught.

The success of the implementation of multicultural education in classroom learning is very dependent on the central role of the teacher, because the teacher's awareness of multiculturalism will frame the teacher's assumptions about how to teach, the material to be taught and about students. Charles et al (2013) argue that advancing multicultural education is a difficult task, which presents challenges for educators. Wells (2008) emphasizes that teaching multicultural students is difficult for teachers who are not well-trained, are not aware of multiculturalism, or have not interacted / experienced with multiculturalism. These teachers find it difficult to incorporate multicultural goals, teaching methods, assessment materials and activities into the curriculum because they are afraid that if they include these activities, they may not function properly, because their understanding of instructional goals is not optimal. Instructional goals according to experts are associated with behavioral goals that students want to achieve according to competence (Magner, 1962), behaviors that describe student learning outcomes (Dejnozka and Kavel, 1981) and expected skills as a result of learning (Percival, F and H. Ellington, 1984).

Based on the results of this study, the researchers argue that teacher awareness about multiculturalism is an important factor that will support multicultural implementation in classroom learning. This is in line with the opinion of Borg (2011) that in general teacher beliefs provide a basis for their actions and also influence their orientation as teachers (Fives \& Buehl, 2012). In class, teachers must be able to find the most effective ways to overcome the challenges of diversity that come from their students (Keengwe, 2010), this is not easy for teachers to do, especially if multicultural education has not been adopted in the curriculum.

SMAK Kesuma is one of the favorite private high schools in the province of West Nusa Tenggara (NTB), and has a high diversity when viewed from the background of students, teachers and school managers, and so far, there has never been a significant conflict due to the diversity that is owned. The challenge faced by schools in this region is that there are still frequent social conflicts in the community caused by small problems that originate from diversity such as ethnicity and religion. Therefore, schools have a responsibility to develop multicultural values to answer these challenges. The teacher is one component of the school that can directly influence the attitudes of students through classroom learning, therefore teacher awareness about multiculturalism is important to study. 
Multicultural awareness in this study is limited to aspects of awareness associated with the school's vision and mission, curriculum and teaching as well as the school environment. The purpose of this study was to determine the level of teacher awareness about multiculturalism in curriculum and instructional management at SMAK Kesuma. It is expected that the results of this study can provide consideration for school managers to find out the strengths and difficulties of teachers in order to develop multicultural education in curriculum and instructional at the secondary school level.

\section{METHOD}

This research is a quantitative descriptive study that describes teacher awareness about multiculturalism in curriculum and instructional management at the secondary school level. The subjects of the study were 34 teachers at SMAK Kesuma who were still active as instructors at the school.

Open survey and interview methods were used to obtain data on multicultural awareness in curriculum and teaching management available at Kesuma SMAK NTB. The survey was conducted using a questionnaire developed based on The Multicultural Awareness to School Environment (MASE) by Morote and Tatum (2014) which has been modified primarily for aspects of curriculum and teaching and the school environment, and added to aspects of vision, mission and school policy. Questionnaire consists of 30 statements distributed in 3 aspects, 10 items for vision, mission and school policy aspects, 15 items for curriculum and teaching aspects and 5 items for school environment aspects.

The choice of answers uses a Likert scale where the respondent gives the level of consent heard score $1=$ Strongly Disagree (STS), score $2=$ Disagree (TS), score 3 $=$ Disagree $(\mathrm{KS})$, score $4=$ Agree $(\mathrm{S})$ and score $5=$ Strongly Agree (SS). Interviews were conducted in a semistructured manner to obtain more in-depth data about multicultural awareness based on the experience of the respondents. The data analysis technique uses descriptive statistics that describe data with a description pattern or review or conclusion so that it is easy to read and meaningful. The percentage index formula describes the level of awareness about multiculturalism and is based on the views of respondents.

\section{RESULT AND DISCUSSION The Profil of SMAK Kesuma NTB}

SMAK Kesuma NTB is one of the most favorite private Catholic schools in NTB with a vision of quality in developing intelligent, independent and character, and having a variety of excellent programs. This school has 605 students and 59 teachers with various tribes and religions as illustrated in Figure 1. Based on religious background, the students who study in this school are predominantly Hindus, then Protestant Christians, Buddhists, Catholics and Muslims, while for the dominant teacher Catholicism, then Hinduism, Islam, Christianity and Buddhism. These data illustrate that SMAK Kesuma is a religious-based but multicultural school (Figure 1; Figure 2).

Teachers assume that multicultural education really needs to be developed in their schools in a variety of activities. The forms of activities or programs that have been carried out by the school starting from the orientation period for new students have been introduced about multiculturalism by the Student Council and its preparation. The school has also provided a variety of extracurricular activities that can be used to accommodate the diversity of student interests such as arts, sports, nature lovers, olympiads, English and Japanese and scouts. Multicultural values on national aspects are also provided in the form of activities to commemorate Kartini Day and Youth Oath Day, where at that time all students and teachers used traditional clothing from their respective regions.

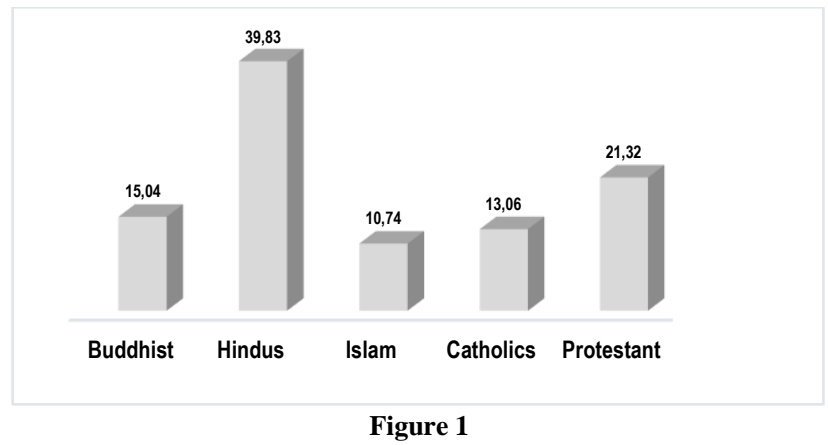

Religious Diversity of Students

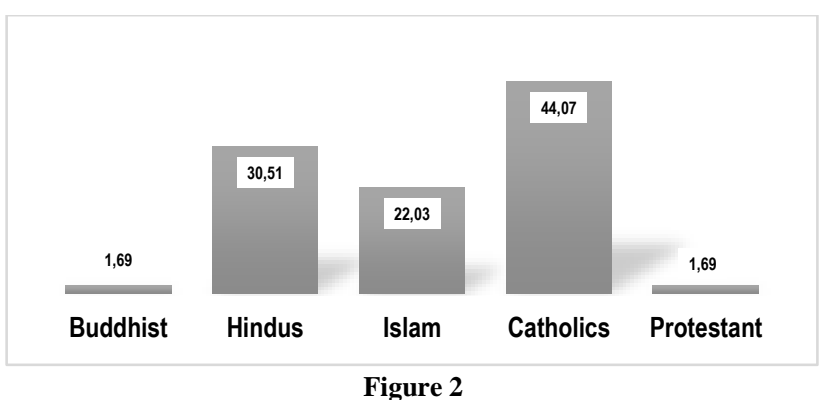

Religious Diversity of Teacher

This shows that schools have realized the importance of providing equal opportunities for students to achieve academic achievement in accordance with the vision, mission and goals of education to be achieved. Some activities that have been provided by the school help the teacher to get to know more about the culture, interests and attitudes of each of their students and according to Smith (2009) this will greatly help the teacher in overcoming the diversity of students during classroom learning. Manson (1999) emphasizes that teachers who do not know their students well result in a low level of educational completion for most minority students.

Some studies reveal that the role of the principal in multicultural education is very important (Furman, 2012; Ylimaki \& Jacobson, 2012). From the results of interviews with principals it is known that principals consider multicultural education to be accommodated and fostered continuously because in their schools the level of diversity is very high, both from ethnicity, religion, race and socioeconomic class. The principal as a manager realizes the need to accommodate diversity in policies and activities, such as the provision of various programs to facilitate all students to achieve optimal achievement. 
While in classroom learning to facilitate the formation of multicultural attitudes, the principal has made a policy to insert in lessons about nationalism and respect for differences. Principals, teachers, education staff and students have understood about multicultural education with indicators that there is no conflict originating from multicultural differences. The principal's leadership style that supports the formation of cultural values is in line with some of the results of previous research that multicultural leadership of principals must be able to provide support, direction and innovation to its members in decisionmaking processes (Balyer, 2012; Dvir et al., 2002; Matthew , 2016; Pitre, 2014; Silins et al., 2000).

\section{Teacher Awareness about Multicultural in Curriculum Management and Instructional Development}

Multicultural awareness of SMAK Kesuma teachers in NTB in this survey was reviewed from three aspects, namely vision, mission and school policies, curriculum and teaching, and the school environment. The level of multicultural awareness is calculated using the percentage awareness index, which describes the level of awareness of respondents based on the perspective held by the respondents.

The survey results showed that teachers' awareness including very high categories with awareness index above $90 \%$ for all aspects (Table 1), but if viewed from the magnitude of the contribution of teacher awareness about multiculturalism in all aspects in general is still in the low category because it is less than $50 \%$.

This fact shows that high teacher awareness cannot directly increase contributions in the management of curriculum and teaching. High teacher awareness can be formed from teacher experience in dealing with multicultural conflict situations that often occur around the environment, as reported by Nayaka (2018) and Walkinton (2015) that teachers who have diversity experience will be highly motivated to teach diversity in their schools, experiences as well it is very important to shape the character and perception of teachers towards multicultural education (Eskci \& Cayak, 2018).

Another fact revealed in this study is the still low contribution of teacher awareness on all aspects studied including aspects of the curriculum and teaching. This result is in line with the study of Raihani (2017) that multicultural education in Indonesia has not been implemented consistently, even though the policy already exists but its implementation still faces many obstacles, including: there is no clear policy and vision that can bind all school components to teach multicultural education, and curriculum content has not provided enough space to teach multicultural concepts and values.

Another factor that is thought to play a role in the low contribution of teacher awareness to curriculum development is the factor of teacher knowledge and skills, because there are still many teachers who have difficulty in pouring multicultural values into planning (RPP) especially in developing instructional goals and during classroom learning. Therefore, some researchers suggest the importance of training for teachers so that teachers have good knowledge and skills so they are able to overcome obstacles in teaching multicultural values in the classroom (Keskin, 2018).

Teacher awareness about multiculturalism in each aspect is given in Table 2 to Table 4. Awareness related to aspects of vision, mission and school policy is reviewed in 10 items of statements and the results show teacher awareness index in high category (Table 2).

Table 1

SMAK Kesuma Teacher Multicultural Awareness Index

\begin{tabular}{|c|c|c|c|}
\hline Aspect & $\mathbf{N}$ & Awareness Index (\%) & Constribution Factor $(\%)$ \\
\hline 1. School vision, mission and policy & 34 & 94,71 & 31,57 \\
\hline 2. Curriculum and instruction & 34 & 92,43 & 46,22 \\
\hline 3. School environment & 34 & 94,82 & 15,80 \\
\hline Total aspect & 34 & 93,59 & \\
\hline
\end{tabular}

Table 2

Multicultural Awareness Index related to School Vision, Mission and Policy

\begin{tabular}{|c|l|c|c|}
\hline Item & \multicolumn{1}{|c|}{ Vision, Mission and School Policy } & \% Index \\
\hline 1 & $\begin{array}{l}\text { The vision and mission of the school reflects equality of education with a diversity of etnic, religions and } \\
\text { cultures in Indonesia }\end{array}$ & $\begin{array}{l}\text { Nchool vision and mission provide opportunities for teachers and students to develop knowledge about } \\
\text { multiculturalism }\end{array}$ & 34.65 \\
\hline 3 & $\begin{array}{l}\text { There is a policy to improve teacher skills in modifying learning so that minority students have equal } \\
\text { opportunities for achievement }\end{array}$ & 34.65 \\
\hline 4 & $\begin{array}{l}\text { The school program helps teachers to identify students' attitudes / personalities based on ethnic background, } \\
\text { religion, culture, language and social status }\end{array}$ & 34 \\
\hline 5 & $\begin{array}{l}\text { The school program helps teachers to understand how to interact with students who have a diversity of religions, } \\
\text { ethnicities, cultures and social status }\end{array}$ & 34 & 34.94 \\
\hline 6 & School holidays reflect multiethnic and multicultural diversity in Indonesia & 93.53 \\
\hline 7 & School policies provide opportunities for principals, teachers and staff to come from diverse cultures & 34 & 95.88 \\
\hline 8 & Teachers and staff in minority schools have the same experience, position and support as in other schools & 34 & 93.53 \\
\hline 10 & $\begin{array}{l}\text { The principal is responsible for providing multicultural training and comprehensive sensitivity for teachers and } \\
\text { staff }\end{array}$ & 34 & 90.00 \\
\hline 23 & It is important for teachers to accept cultural diversity and sensitivity training on an ongoing basis \\
\hline
\end{tabular}


Of the 10 questions surveyed, there were two questions that had a lower percentage of awareness index than the others, which were related to school policies for providing multicultural training and sensitivity for teachers and staff (90\%), and school programs to help teachers identify students based on diversity $(92.94 \%)$. The teacher believes that schools need to facilitate multicultural training to assist them in classroom teaching. Several studies have reported that training in multicultural education is needed by teachers to be able to instill multicultural values in their teaching (Keskin, 2018; Daniel \& Pray, 2016; Webster-Wright, 2009). Even according to Kyles \& Olafson (2008) experience when education or training will affect the teacher's beliefs and abilities when practicing as a teacher in the classroom.

Helping teachers to be more competent in teaching about multicultural values must be accompanied by policies to provide opportunities for teachers to develop themselves professionally. Self-development can be done through a variety of programs, for example, further education, seminars, workshops, or other activities with the aim of improving the achievement of school goals. Professional development and training that focuses on multiculturalism must include understanding that differences are not always weaknesses (Sleeter \& Grant, 2009), rather, seeing differences as strengths will help teachers become more culturally competent. But this selfdevelopment is also very dependent on the attitudes and awareness of teachers and principals, for example, how much they believe that training or education can help them work more effectively, or also the attitude of teachers who are resistant to the efforts for professional development offered.

Some positive values revealed in this survey include vision, mission and school policies that reflect diversity, and provide equal opportunities for teachers and staff to develop their knowledge. The core of this approach is the vision, mission and school policies that serve as directives and guidelines for multicultural education. Leadership plays a role in regulating other elements to realize the vision and mission, while management ensures the stability of the process by imposing managerial functions.

The quality of curriculum and teaching is at the heart of the process, and provides the main resources for children to learn to understand cultural diversity and develop attitudes that are appropriate for their purpose. The purpose and curriculum content that explicitly contains the teachings of multiculturalism is a reflection of the school's vision, and teaching that can facilitate the achievement of school goals. According to Aydin (2012), students who have diverse cultures need education that teaches values of cultural diversity, but often schools also have limitations in cultural awareness and competence, as experienced by schools in Turkey, so schools seek solutions with adopt and restructure curricula from other countries.

Multicultural awareness related to curriculum and the development of teaching in SMAK Kesuma is included in the very high category $(92.43 \%)$ although it is still lower than the other two aspects. Based on Table 3, it shows that multicultural awareness related to curriculum and teaching still has a number of items whose value is low, namely item number $18(78.82 \%)$ about extracurricular activities that emphasize cross-ethnic, religious and cultural membership, and item number 25 (89.41\%) about relevance of multicultural awareness to the subject taught by the teacher.

Extracurricular activities have been sufficiently facilitated by schools but teachers assume that the emphasis on cross-cultural group membership is still not optimal. In addition to teacher awareness, student attitudes toward diversity also influence the programs developed by the school. The culture of students at home is sometimes difficult to implement in schools so teachers need to design the right strategies to overcome these problems because teacher awareness will influence student attitudes as stated by Russell and Russell (2014) that perceptions, attitudes, beliefs and expectations of the teacher play important role in student performance.

Table 3

Multicultural Awareness Index Related to Curriculum and Instructional Development

\begin{tabular}{|c|c|c|c|}
\hline Item & Curriculum and Instructional Development & $\mathbf{N}$ & $\%$ Index \\
\hline 11 & The curriculum reflects a variety of learning styles in accordance with diversity in school & 34 & 93.53 \\
\hline 12 & The curriculum provides sufficient opportunities for the development of multicultural values & 34 & 94.71 \\
\hline 13 & The curriculum helps students use unique experiences from a diversity perspective & 34 & 94.71 \\
\hline 14 & The curriculum helps develop tolerance and respect for diversity & 34 & 92.94 \\
\hline 15 & Teaching materials used reflect cross religion, ethnicity, culture and gender & 34 & 91.18 \\
\hline 16 & $\begin{array}{l}\text { Learning strategies used by teachers provide opportunities for students from various cultural groups to } \\
\text { participate }\end{array}$ & 34 & 92.94 \\
\hline 17 & Objectives, goals, assessments and co-curricula reflect the presence of multicultural values & 34 & 94.71 \\
\hline 18 & The teacher makes extracurricular activities by emphasizing cross-ethnic, religious and cultural membership & 34 & 78.82 \\
\hline 19 & $\begin{array}{l}\text { The teacher organizes activities that enable cross-ethnic, religious and cultural membership to work } \\
\text { cooperatively }\end{array}$ & 34 & 92.35 \\
\hline 20 & Teachers modified teaching strategies to accommodate ethnic, religious and cultural diversity & 34 & 91.76 \\
\hline 21 & The teacher is responsible for mixing relevant cultural activities into the curriculum & 34 & 90.59 \\
\hline 22 & $\begin{array}{l}\text { Students are taught about the values used by almost all cultures, such as justice, equality, freedom, peace, } \\
\text { compassion, and charity }\end{array}$ & 34 & 96.47 \\
\hline 24 & It is important for all students to be aware of the cultural differences between them & 34 & 96.47 \\
\hline 25 & Multicultural awareness is relevant for the subject I teach & 34 & 89.41 \\
\hline 26 & Multicultural awareness helps me be more effective at work & 34 & 95.88 \\
\hline
\end{tabular}

Many factors influence teacher awareness about multiculturalism, including limited teacher knowledge, not being able to promote tolerance and diversity as part of the subject curriculum; also distrust that multicultural education is one of the responsibilities of their education (Raihani, 2017). Pewewardy (2005) proposes that teachers 
be more effective in teaching students in diverse classes, teachers must be committed to understanding the culture and views of their students. In other words, so that the teacher must know his students, interact with them so they can see their world from a variety of cultural lenses, which in turn will help teachers to link multicultural values in their teaching.

The survey results show that teachers have not optimally integrated multicultural concepts into their subjects, so that they have not been able to produce responsive learning for the diversity of their students' cultures, because in reality teachers have difficulty connecting the multicultural values into the subjects they are teaching. They generally consider multicultural education to be only the responsibility of certain subjects.

As suggested by Cooper et al. (1998) the involvement of school elements including school policies, teachers, management, parents, students and school boards in various activities and processes to produce effective multicultural education is very important. Multicultural education can be understood through improvements in various fields, for example: policies for access and equality for cross-social groups, in the field of padagogy there is an increase in diversity of students in the classroom, curriculum fields include the development of material to be taught / learned in the form of facts, attitudes or skills related to partitions (Banks 2009).

While Siwatu (2007) revealed that pedagogically responsive learning on cultural diversity at least includes 4 elements, namely: (1) using students' cultural knowledge (for example, culturally known scenarios, examples and sketches), experience, prior knowledge, and individual learning preferences, as channels to facilitate the teachinglearning process (curriculum and teaching); (2) combining students' cultural orientation to design a culturally compatible class environment (class management); (3) provide many opportunities for students to show what they have learned using various assessment techniques (student assessment); and (4) providing necessary knowledge and skills about cultural functions while simultaneously helping students maintain their cultural identity, native language, and connections to other cultures (cultural enrichment and competence).

The third aspect studied in this study is teacher awareness related to the school environment. School environment is interaction and behavior patterns between all school members, including parents. School personnel, students, and their parents, help shape values, beliefs, traditions and assumptions about the school environment through "prior experience, community settings, cultural background, and ethnic identity (Irvine, 2003).

The survey results show that teacher awareness about multiculturalism related to school environment is very high and from Table 4, although the contribution of teacher awareness on this aspect is low but environmental factors are very important to shape student attitudes, so cooperation with other institutions needs to be improved.

Table 4

Multicultural Awareness Index Related to School Environment

\begin{tabular}{|c|l|c|c|}
\hline Item & \multicolumn{1}{|c|}{ School environment } & N & Index \\
\hline 9 & $\begin{array}{l}\text { The principal ensures that the school environment accommodates a diversity of different ethnicities, religions, } \\
\text { languages and cultures }\end{array}$ & 34 & 94.71 \\
\hline 27 & Parents have a responsibility to teach multicultural values to their children & 34 & 96.47 \\
\hline 28 & Students in my school have diverse cultural backgrounds & 34 & 97.06 \\
\hline 29 & Parents of students from ethnic and cultural backgrounds participate in planning school activities & 34 & 93.53 \\
\hline 30 & The school collaborates with various elements of a cross-cultural community & 34 & 92.35 \\
\hline
\end{tabular}

\section{CONCLUSION}

Based on the results of the study described, it was concluded that the awareness of multicultural SMAK Kesuma teachers in the three aspects studied were: vision, mission and school policies, curriculum and teaching as well as the school environment, in general including very high categories (>90\%), but if in terms of the contribution of multicultural awareness to each aspect, it is quite low (< $50 \%$ ). This shows that the teacher's awareness of multiculturalism does not necessarily increase the contribution to the management of curricula and instructional.

This study also identified several supporting factors as well as obstacles to the management of curriculum and instructional development related to multiculturalism. Some supporting factors include: (1) vision, mission and school policies have accommodated the multicultural values that want to be developed at the school level; (2) the curriculum provides an opportunity to develop multicultural values; (3) the teacher has a high awareness of the importance of teaching multicultural values; and (4) the principal has a policy to accommodate diversity through programs in the school.
Some inhibiting factors include: (1) clear and binding policies for all components to teach multicultural values have not been formally formulated; (2) the teacher's awareness of multicultural education is still limited to an understanding of aspects of the majority of religion; and (3) the development of multicultural values in teaching is not optimal because of the limited space in the curriculum, knowledge and skills of teachers. Collaboration with various parties to develop multicultural values still needs to be improved.

\section{REFERENCE}

[1] Aydin, H. 2012. Multicultural Education Curriculum Development in Turkey. Mediterranean Journal of Social Sciences, 3(3), 277-286.

[2] Arneil, B., \& F. MacDonald. 2010. Multiculturalism and the Social Sphere. In Ivison, D., (ed.), The Ashgate Research Companion to Multiculturalism. London: Routledge.

[3] Banks, J. A. 2009. The Routledge International Companion to Multicultural Education. London: Routledge. 
[4] Banks, J. A., \& Banks, C. A. M (Eds.). 2004. Handbook of Research on Multicultural Education. San Francisco: Jossey-Bass.

[5] Banks, J. A. 2006. Cultural Diversity and Education: Foundations, Curriculum, and Teaching. Boston: Allyn and Bacon.

[6] Banks, J. A., \& Banks, C. M. (Eds.) 2010. Multicultural Education: Issues and Perspectives. Hoboken, NJ: John Wiley \& Sons

[7] Bennett, C. 2001. Genres of Research in Multicultural Education. Review of Education Research, 71, 171-217.

[8] Borg, S. 2011. The Impact of In-Service Teacher Education on Language Teachers' Beliefs. System, 39 (3), 370-380.

[9] Hoon, C. Y. 2013. Multicultural Citizenship Education in Indonesia: The Case of a Chinese Christian School. Journal of Southeast Asian Studies, 44(03), 490-510.

[10] Charles, H., Longerbeam, S. D. \& Miller A, E. 2013. Putting old Tensions to Rest: Multicultural Education and Global Learning to Advance Student Development. Journal of College \& Character, 14(1), 47-57.

[11] Cooper, M., Burman, E., Ling, L., Razdevsek-Pucko, C., \& Stephenson, J. 1998. Practical Strategies in Values Education. In Joan Stephenson, Lorraine Ling, Eva Burman \& Maxine Cooper (Eds.). Values in Education (p. 161194). London: Routledge.

[12] Daniel, S. M., \& Pray, L. 2016. Learning to teach English Language Learners: A Study of Elementary School Teachers' Sense Making in an ELL Endorsement Program. TESOL Quarterly, 51(4), 787-819.

[13] Eskici, M., \& Çayak, S. 2018. Teachers' Personal Characteristics and Metaphorical Perceptions to Multicultural Education. Journal of Education and Training Studies, 6(3a), 98-108.

[14] Fives, H., \& Buehl, M. 2012. Spring Cleaning for the 'Messy' Construct of Teachers' Beliefs: What are They? Which have Been Examined? What can They Tell Us? In K. Harris, S. Graham, \& T. Urdan (Eds.). APA educational psychology handbook: Vol. 2. Individual Differences and Cultural Contextual Factors (p. 471-499). Washington, DC: American Psychological Association.

[15] Faas, D., \& Ross, W. 2012. Identity, Diversity and Citizenship: A Critical Analysis of Textbooks and Curricula in Irish schools. International Sociology, 27(4), 574-591.

[16] Furman, G. (2012). Social Justice Leadership as Praxis: Developing Capacities Through Preparation Programs. Educational Administration Quarterly, 48(2), 191-229.

[17] Gay, G. 2013. Teaching to and Through Cultural Diversity. Curriculum Inquiry, 43 (1), 48-70.

[18] Gorski, P. C. 2010. The Challenge of Defining Multicultural Education. Retrieved 2 June 2019, from http://www.edchange.org/multicultural/initial.html.

[19] Hampden-Thompson, G., Jeffes, J., Lord, P., Bramley, G., Davies, I., Tsouroufli, M. \& Sundram, V. 2015. Teachers' Views on Student's Experiences of Community Involvement and Citizenship Education. Education Citizenship and Social Justice, 10(1), 67-78.

[20] Irvine, J. J. 2003. Educating Teachers for Diversity: Seeing with a Cultural Eye. New York: Teachers College Press.

[21] Jackson, E. J. 2014. Under Construction: The Development of Multicultural Curriculum in Hong Kong and Taiwan. Asia-Pacific Education Researcher, 23 (4), 885-893.

[22] Kang, S. W. 2010. Multicultural Education and the Rights to Education of Migrant Children in South Korea. Educational Review, 62(3), 287-300.

[23] Keskin, S. C. 2018. Problems and Their Solutions in a Multicultural Environment According to Pre-service Social Studies Teachers. Journal of Education and Training Studies, 6(7), 138-149.
[24] Kyles, C., \& Olafson, L. 2008. Uncovering Preservice Teachers' Beliefs about Diversity Through Reflective Writing. Urban Education, 43, 500-518.

[25] Listia, L. A., \& Lian, G. 2007. Problematika Pendidikan Agama di Sekolah (The Problems of Religious Education in School). Yogyakarta: Institut Dian / Interfidei.

[26] Lie, A. 2000. The Multicultural Curriculum: Toward Education for Peace and Development. SEAMEO Jasper Fellowship Monograph Series, 4, 101-150.

[27] Lie, J. (ed.). 2014. Multiethnic Korea, Multiculturalism, Migration, and Peoplehood Diversity in Contemporary South Korea. Berkeley: Institute of East Asian Studies, University of California.

[28] May, S., \& Christine, E. S. 2010. Introduction: Critical Multiculturalism: Theory and Praxis. In Stephen May and Christine E. Sleeter (Ed.). Critical Multiculturalism: Theory and Praxis. New York: Taylor \& Francis.

[29] Mitchell, A. 2010. Peace Beyond Process? Millennium. Journal of International Studies, 38(3), 641-664.

[30] Morote and Tatum. 2014. A Reliable Survey to Measure Teachers Multicultural Awareness to Their School Environment. Retrieved 2 June 2019. from https://www.researchgate.net/publication/228518209.

[31] Nayaka, A. 2018. Overcoming Ethnic Conflict through Multicultural Education: The Case of West Kalimantan, Indonesia. International Journal of Multicultural Education, 20 (1), 119-137.

[32] Keengwe, J. (2010). Fostering Cross Cultural Competence in Pre-Service Teachers Through Multicultural Education Experiences. Early Childhood Education Journal, 38, 197204.

[33] Pewewardy, C. (2005). Shared Journaling: A Methodology for Engaging White Pre-Service Students in Multicultural Education Discourse. Teacher Education Quarterly, 32, 4160

[34] Raihani. 2011. A Whole-School Approach: A Proposal for Education for Tolerance in Indonesia. Theory and Research in Educatio, 9(1), 23-39.

[35] Raihani. 2017. Education for Multicultural Citizens in Indonesia: Policies and Practices. Compare: A Journal of Comparative and International Education, 48(6), 9921009.

[36] Ratnawati. 2017. Signifikansi Penguasaan Guru terhadap Psikologi Siswa dalam Proses Belajar Mengajar. Jurnal Pendidikan dan Pembelajaran Dasar, 4(2), 48-64.

[37] Rochana, T., Rachman, M., Slamet, A., \& Rifai, A. 2018. Developing a Multicultural-Based Sociology Instructional Training Management Model to Improve the Teachers' Professional Competence in Semarang City. The Journal of Educational Development, 6(3), 312-322.

[38] Russell, M. \& Russell, J. A. (2014). Pre-service teachers and cultural diversity awareness. Electronic Journal of Science Education, 18(3), 1-20.

[39] Simmons, J. C. 2016. Multicultural Leadership Characteristics of a School Director in An Educational Setting in South Korea: A Case Study. Dissertation. Liberty University, Lynchburg, VA.

[40] Siwatu, K. O. 2006. Pre-Service Teachers' Culturally Responsive Teaching Self-Efficacy and Outcomes Expectancy Beliefs. Teacher and Teacher Education, 23(2), 1086-1110.

[41] Slameto. 2010. Belajar dan Faktor-faktor yang Mempengaruhi. Jakarta: Rineka Cipta.

[42] Sleeter \& Grant. 2009. Making Choices for Multicultural Education: Five Approaches to Race, Class and Gender. New York: John Wiley \& Sons, Inc.

[43] Walkington, J. 2015. Enhancing Multicultural Perspectives in the Formation of Preservice Teachers Through 
Immersion in a Culturally Different Context. Multicultural Education Review, 7(3), 140-154.

[44] Warren, A. N. 2018. Exploring Experienced Teachers' Constructions of Culturally and Linguistically Diverse Students in an Online Class. International Journal of Multicultural Education, 20(2), 58-80.

[45] Wells, R. (2008). The Global and the Multicultural: Challenges and Suggestions for Teacher Education. The Journal of the National Association for Multicultural Education, 10(3), 142-149.
[46] Webster-Wright, A. 2009. Reframing Professional Development Through Understanding Authentic Professional Learning. Review of Educational Research, 79, 702-739.

[47] Ylimaki, R. \& Jacobson, S. (2012). School Leadership and Preparation: Comparative Perspectives on Organizational (OL), Instructional Leadership (IL) and Culturally Responsive Practices (CRP). Journal of Educational Administration, 51(1), 6-22. 